\title{
A MODIFICATION OF THE KROGH CARBON MONOXIDE BREATH HOLDING TECHNIQUE FOR ESTIMATING THE DIFFUSING CAPACITY OF THE LUNG; A COMPARISON WITH THREE OTHER METHODS ${ }^{1}$
}

\author{
By R. E. FORSTER, J. E. COHN, ${ }^{2}$ W. A. BRISCOE, ${ }^{3}$ W. S. BLAKEMORE, 4 AND \\ R. L. RILEY \\ (From the Departments of Physiology-Pharmacology and Anesthesiology, of the Graduate \\ School of Medicine, University of Pennsylvania, the Departments of Environmental \\ Medicine and Medicine, Johns Hopkins University, and the Harrison Department \\ of Surgical Research, the School of Medicine, University of Pennsylvania)
}

(Submitted for publication October 25, 1954 ; accepted May 11, 1955)

There are at present four methods for assessing the pulmonary diffusing capacity $(\mathrm{D})$, one using $\mathrm{O}_{2}\left(\mathrm{Do}_{2}\right)$ and three using $\mathrm{CO}\left(\mathrm{D}_{\mathrm{co}}\right)$ namely, the $\mathrm{O}_{2}$ method of Lilienthal, Riley, Proemmel, and Franke (1), the steady state CO method of Filley, MacIntosh, and Wright (2) and the $\mathrm{CO}$ breath holding technique of $\mathrm{Krogh}$ and $\operatorname{Krogh}(3,4)$ as modified by some of the authors (5), all of which provide estimates of the pulmonary diffusing capacity, and finally the fractional $\mathrm{CO}$ uptake of Bates (6) which gives an index of pulmonary diffusing capacity. This is a report of a cooperative research effort to compare these methods as nearly simultaneously as possible on six patients and one normal subject. Measurements were made over the extremes of pulmonary diffusing capacity, from a patient with a severely decreased pulmonary diffusing capacity at rest (Subject 5) to a normal subject during exercise (Subject 1).

\section{METHODS}

\section{A. Steady state $D_{\mathrm{O}_{2}}$ method}

This method requires the simultaneous sampling of expired gas and arterial blood with the subject breathing first air and then a low concentration of $\mathrm{O}_{2}$. Analysis of the alveolar-arterial $\mathrm{PO}_{2}$ gradient under these two conditions makes possible the estimation of the mean alveolar-capillary $\mathrm{PO}_{2}$ difference, which is divided into the $\mathrm{O}_{2}$ uptake to give $\mathrm{Do}_{2}$. This technique has been adequately

1 Supported by a grant from the Life Insurance Medical Research Fund and aided by a contract between the Office of Naval Research, Department of the Navy, and Johns Hopkins University (NR 112-101).

2 Present Address: Chest Service, Bellevue Hospital, New York, New York.

8 Present Address: M.R.C. Pneumoconiosis Unit, LLandough Hospital, Penarth, Wales.

4 American Cancer Scholar. described in detail before $(1,7,8)$, the only significant alteration in previous procedure was in the gas mixtures breathed. For an initial period of equilibration of 5 to 12 minutes the subject inspired a predetermined $\mathrm{O}_{2}$ and $\mathrm{N}_{2}$ mixture from a compressed gas tank. At the end of this period, the patient was suddenly switched to inspire a gas mixture containing the same percentages of $\mathrm{O}_{2}$ and $\mathrm{N}_{2}$ and in addition approximately 0.1 per cent $\mathrm{CO}$. After breathing this mixture for a further 1 to 2 minutes, the collection period was started as usual, (1). This procedure permitted simultaneous steady state estimates of $\mathrm{DO}_{2}$ and $\mathrm{D}_{\mathrm{co}}$, with a minimal total $\mathrm{CO}$ uptake. Although all but two of the seven individuals were studied during exercise, we do not know whether the values of $\mathrm{DO}_{2}$ and steady state Dco are maximal diffusing capacities (7) or not.

\section{B. Steady state $D_{\text {co }}$ method}

This procedure has been described in detail by Filley, MacIntosh, and Wright (2) and will not be fully discussed here. In general it consists of establishing steady state conditions while breathing a mixture containing 0.1 to 0.15 per cent $\mathrm{CO}$, and measuring the inspired and expired $\mathrm{CO}$ and $\mathrm{CO}_{2}$ concentrations, plus the arterial $\mathrm{PCO}_{2}$. From the ventilation and the $\mathrm{CO}$ concentrations, the $\mathrm{CO}$ uptake can be calculated. As in the method of Lilienthal, Riley, Proemmel, and Franke (1), arterial $\mathbf{P C O}_{2}$ is considered equal to mean alveolar $\mathrm{PCO}_{2}$ and, along with the values above, is used to calculate alveolar $\mathrm{P}_{\text {co. }}{ }^{5}$ This value for effective alveolar $P_{c o}$ is divided into

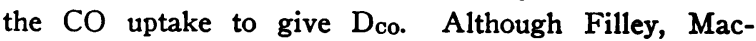
Intosh, and Wright used a 6-minute preliminary period breathing the $\mathrm{CO}$ mixture (2), Bates (6) and ourselves (9) found that 1 to 2 minutes sufficed to reach a sufficiently steady state under these circumstances. Analyses of $\mathrm{CO}$ concentration in the various gases were made with an infra red gas analyzer, ${ }^{6}$ instead of by the chemical method used by Filley, MacIntosh, and Wright (2).

A simple version of the equation used is:

$$
\begin{aligned}
& \text { alveolar } \mathrm{P}_{\mathrm{Co}}=\text { inspired } \mathrm{P}_{\mathrm{Co}}-\frac{\text { arterial } \mathrm{P}_{\mathrm{CO}_{2}}}{\text { expired } \mathrm{P}_{\mathrm{CO}_{2}}} \\
& \text { (inspired } \left.\mathrm{P}_{\mathrm{Co}}-\text { expired } \mathrm{P}_{\mathrm{Co}}\right) . \\
& { }^{6} \text { Liston-Becker Co., Stamford, Conn. }
\end{aligned}
$$




\section{Fractional CO uptake}

This is

$\mathrm{CO}$ absorption in $\mathrm{ml} . / \mathrm{min}$.

CO inspired in $\mathrm{ml} . /$ minute (corrected for

instrumental dead space)

The data were available from the determinations of $D_{c o}$ by the steady state technique, and were not collected in a separate procedure as described by Bates (6).

\section{Breath holding technique for $D_{c o}$}

We regarded this study as an opportunity to compare the modified Krogh breath holding technique for measuring pulmonary diffusing capacity with the other methods and to obtain simultaneous rather than consecutive comparisons of Dco steady state with $\mathrm{Do}_{2}$. We have previously published a detailed analysis of a modification of the Krogh breath holding technique, which utilizes 10 per cent $\mathrm{He}$ along with a small concentration of $\mathrm{CO}$ in the inspired mixture to permit correction for the effects of uneven distribution of inspired gas throughout the lung upon the calculation of $\mathrm{D}_{\text {co }}$ (5). In addition to the effects of uneven inspired gas distribution upon the calculated $D_{c o}$, there is the effect of duration of breath holding: calculated $D_{c o}$ decreases with the duration of breath holding (5). Nevertheless, it seemed worthwhile to determine whether careful standardization of the test might provide clinically useful values for $D_{c o}$. The desirability of developing a quick and repeatable clinical test with minimal discomfort to the patient justified the inclusion of the single breath procedure. We have arbitrarily chosen a 10 -second period for breath holding because all the patients studied were able to hold their breath this long, because the resulting change in alveolar $\mathrm{CO}$ concentration was large enough to measure accurately, and because the values for $D_{c o}$ at 10 seconds are reasonably comparable to those in the literature. Although a series of 5 to 9 estimations of $D_{c o}$ was made on each individual at different periods of breath holding up to his limit, or to 60 seconds, only those values obtained with breath holding periods from 9 to 15 seconds

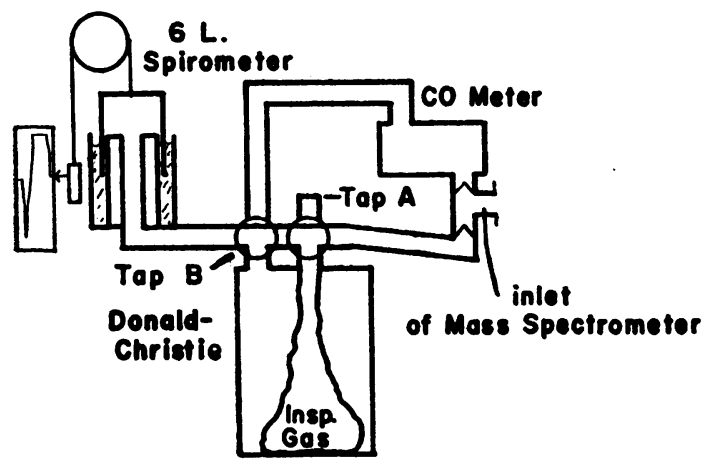

Fig. 1. Diagram of the Apparatus Used to Measure Dco by the Breath Holding Technique

Tap $A$ and Tap $B$ were used in making up gas mixtures.

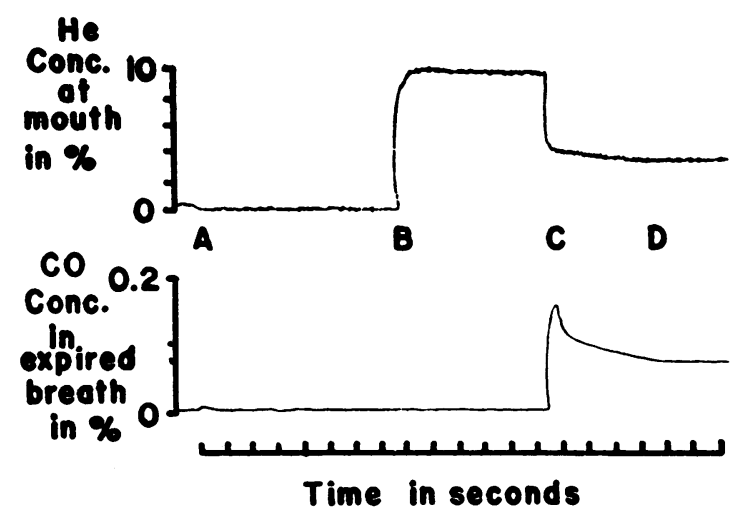

Fig. 2. Record from Patient 2 Showing the He Concentration in the Gases at the Mouth and the CO Concentration in Expired Gas as Used in the Determination of Dco BY the Breath Holding TechNIQUE

are included. A variation of the duration of breath holding between these particular limits caused changes in the calculated $D_{c o}$ of less than 10 per cent judging by the individual graph of expired alveolar $\mathrm{CO}$ concentration versus time of breath holding. The range of 9 to 15 seconds represents extremes of actual breath holding times in inexperienced patients attempting to hold their breaths for the standard 10 seconds. The slow rate of expiration in some patients made the actual breath holding time greater than 10 seconds more often than it was less than 10 seconds.

The apparatus (Figure 1) and method of measuring the breath holding $D_{c o}$ differed from that described previously (5) mainly in that the expired breath went directly through a low flow resistance sample chamber in the infra red $\mathrm{CO}$ analyzer and was not collected in a bag for later analysis. Concentration of $\mathrm{He}$ at the mouth was analyzed with a continuously sampling mass spectrometer. ${ }^{7}$ Both the expired $\mathrm{CO}$ and $\mathrm{He}$ concentrations were recorded through DC amplifiers on a Brush magnetic pen ink writer system. Although the He concentration was recorded with a 90 per cent response time of 0.06 second, the slower response time of the infra red analyzer ( 90 per cent in 0.4 second) combined with the lag in time for the washout of the actual analysis chamber $(25 \mathrm{ml}$.) and associated tubing $(100 \mathrm{ml}$.) made it difficult to compare the two records while expiration was in progress. Therefore, the $\mathrm{He}$ and $\mathrm{CO}$ concentrations were compared at the end of expiration, after the infra red $\mathrm{CO}$ analyzer had had time to respond completely to the expired gas that remained in the chamber.

In performing the breath holding Doo determination the patient sat quietly wearing a nose clip. At the end of a normal expiration, he took the mouthpiece in his mouth, expired to his residual volume, and then inspired, as rapidly as possible, a maximal volume from the bag of the Donald-Christie apparatus which contained a

\footnotetext{
${ }^{7}$ Consolidated Engineering Corp., Pasadena, California.
} 
mixture of 0.3 per cent $\mathrm{CO}, 10$ per cent $\mathrm{He}, 20$ per cent $\mathrm{O}_{2}$ and 70 per cent $\mathrm{N}_{2}$. He held his breath for approximately 10 seconds and then expired, again as rapidly as possible, a volume of 1 liter or more.

A record of $\mathrm{He}$ concentration at the mouth and expired $\mathrm{CO}$ concentration is shown in Figure 2. At the beginning of the record there is a slight contamination of $\mathrm{He}$ in the mouth piece which decreases to zero with the start of patient's expiration (A). At $B$, the patient started to inspire and the He concentration at the mouth rose rapidly to 10 per cent. Six seconds after the start of inspiration the patient started to expire (C) and the He concentration at first fell abruptly to 4.4 per cent and then continued to fall throughout the rest of the expiration in a downward sloping "alveolar plateau." At D, 9.8 seconds after the start of inspiration, the patient completed his expiration; the $\mathrm{He}$ concentration remained constant thereafter, and the $\mathrm{CO}$ record leveled off less than one second later. The output of the $\mathrm{CO}$ meter between A and B, when normal expired gas is in the analysis chamber, is considered zero $\mathrm{CO}$ concentration as the patient had previously inspired no CO. The water vapor and $\mathrm{CO}_{2}$ in the expired gas at this point provide an automatic correction for the interference of these gases with the $\mathrm{CO}$ analysis of the expired alveolar sample at D. During inspiration (B) no CO appears in the analyzer because of the valves in the mouthpiece. At $\mathrm{C}$, expired gas containing $\mathrm{CO}$ is blown through the infra red analyzer, the initial peak being inspired gas from the respiratory and instrumental dead spaces. At $D$, the final expired gas is trapped in the analyzer. This $\mathrm{CO}$ concentration and the corresponding final expired alveolar $\mathrm{He}$ concentration are used to calculate the pulmonary diffusing capacity.

In the example illustrated in Figure 2, the concentration of inspired CO was 0.302 per cent (dry) and of inspired He 10 per cent (dry). At point $D$, the final $C O$ concentration was 0.069 per cent (BTS) and that of $\mathrm{He}$ was 3.52 per cent (BTS). Since $\mathrm{He}$ is practically insoluble in the blood relative to $\mathrm{CO}$, the decrease in the $\mathrm{He}$ concentration from 10 per cent in the inspired gas to 3.52 per cent in the expired alveolar gas is entirely a result of its dilution by the residual gas in the lung at the start of inspiration. The inspired $\mathrm{CO}$ concentration must have been decreased by dilution alone to precisely the same degree as the inspired He. Furthermore, the gas within those regions of the lung where significant $\mathrm{CO}$ absorption takes place, must be mixed within at least a tenth of a second after inspiration (10). Therefore, the initial CO concentration, before any absorption into the blood had taken place, of that particular aliquot of the expired gas which was in the infra red analyzer chamber at the end of expiration, must have been $(3.52 / 10.0) \times 0.302$ per cent $C O$, or 0.106 per cent BTS. This calculation of the initial CO concentration in a particular expired gas sample will be true whether the inspired gas was evenly or unevenly distributed and whether the expired sample came from one or a great many different alveoli. According to the equation of
Krogh and Krogh (3),

$$
\begin{aligned}
D_{c o} & =\frac{\text { alveolar volume }(S T P D) \times 60}{\text { time in seconds } \times(B-47)} \\
& \times \operatorname{Ln}\left[\frac{\text { initial expired alveolar CO concentration }}{\text { final expired alveolar CO concentration }}\right] .
\end{aligned}
$$

The alveolar volume equaled the sum of the volume inspired $(1280 \mathrm{ml}$. STPD) plus residual volume $(3780 \mathrm{ml}$. STPD, by the method of Darling, Cournand, and Richards [11]) or $5060 \mathrm{ml}$ : B-47 was $713 \mathrm{~mm}$. $\mathrm{Hg}$ : the time of breath holding, actually the time from the start of inspiration until the end of the expiration, was 9.8 seconds. Thus the breath holding $D_{c o}$ equaled

$$
\frac{5,060 \times 60}{9.8 \times 713} \operatorname{Ln}[0.106 / 0.069]=18.5 \mathrm{ml} . / \mathrm{min} . / \mathrm{mm} . \mathrm{Hg} \text {. }
$$

These measurements of $D_{\text {co }}$ by the breath holding method were made the same day as the measurements of $\mathrm{Do}_{2}$ and the steady state $D_{c o}$ in the majority of patients.

It can be seen in Figure 2 that the expired alveolar $\mathrm{He}$ concentration decreases during the course of a single expiration, which means that the proportion of inspired gas in the expired alveolar gas decreases during the expiration. In the technique originally described by Krogh (4), two alveolar samples were collected, the initial one from the first part of an expiration, and the other from a later part of the same expiration, after an intervening breath holding period of 10 seconds' duration. Since the difference between the $\mathrm{CO}$ concentrations of the two samples was considered wholly a result of diffusion of CO into the blood, an incorrect value of $D_{c o}$ was obtained.8 We avoid this particular difficulty by using the dilution of the inspired $\mathrm{He}$ to calculate the initial $\mathrm{CO}$ concentration of the alveolar sample.

\section{E. Other pulmonary function studies}

Determinations of lung volumes, including residual volume by the method of Darling, Cournand, and Richards (11), maximum breathing capacity, per cent of the vital capacity expired in one second, uneven ventilation estimated by the method of Cournand, Baldwin, Darling, and Richards (12) and by the single breath test of Comroe and Fowler (13), were also carried out on each patient.

\section{SUBJECTS}

The subjects were chosen so as to give as large a range of values for diffusing capacity of the lungs as possible. Pt. 1 was a healthy young male with no evidence of pulmonary disease. Pt. 2 had a history, physical findings and $\mathrm{X}$-ray examination compatible with a

${ }^{8}$ Since the apparent rate of disappearance of $\mathrm{CO}$ is greater than the actual, under these circumstances, the Krogh technique will lead to an overestimate of Doo. If we had used the two-stage expiration technique in the example given above, we would have obtained a $D_{c o}$ of approximately $24 \mathrm{ml}$. per $\mathrm{min}$. per $\mathrm{mm}$. $\mathrm{Hg}$, instead of $18.5 \mathrm{ml}$. per $\mathrm{min}$. per $\mathrm{mm}$. $\mathrm{Hg}$. 


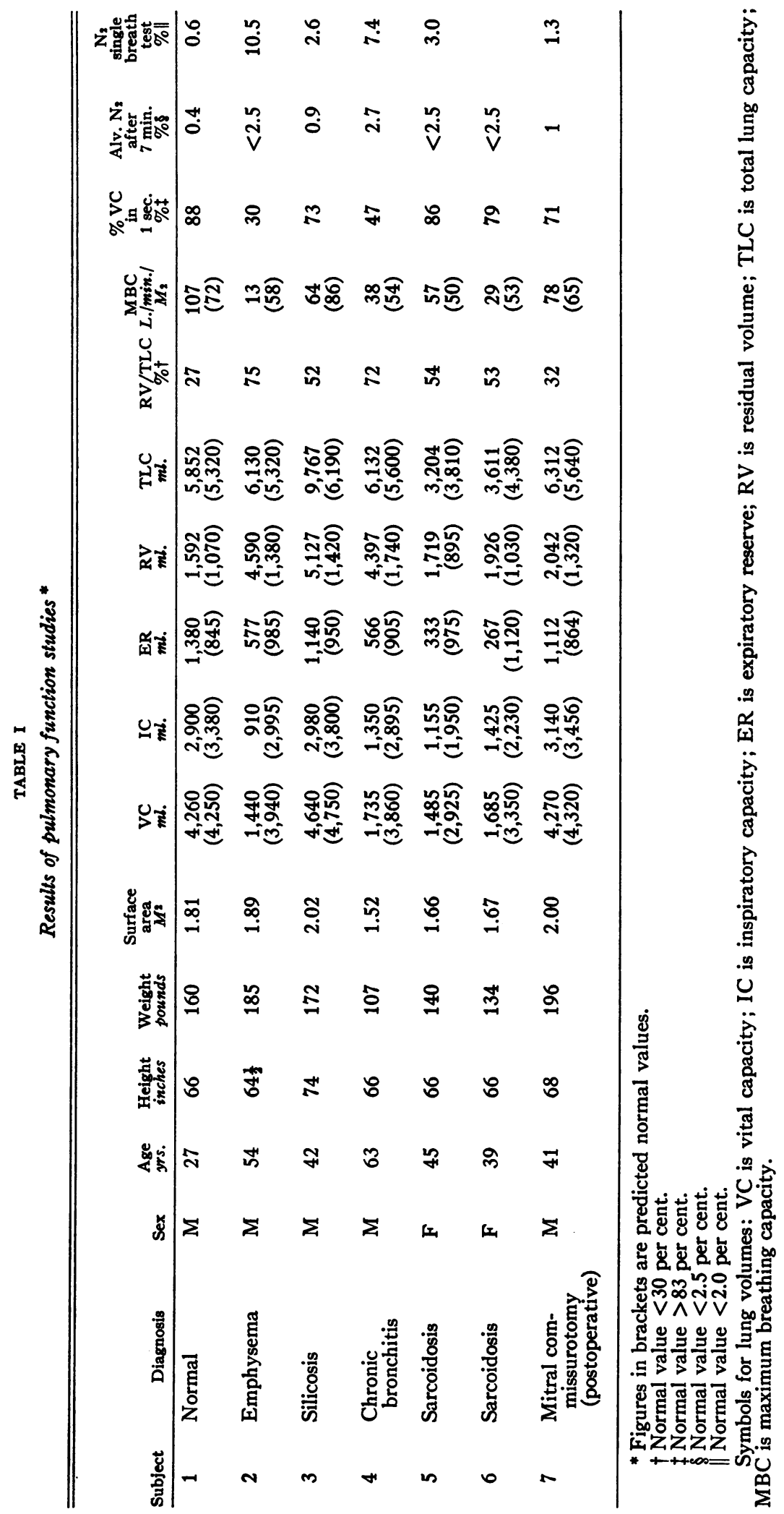


diagnosis of pulmonary emphysema, which was borne out by his pulmonary function tests. He also had a good deal of bronchospasm and, in fact, it was found necessary to use bronchodilators to make him comfortable during the diffusion capacity measurements. Pt. 3 had a history of exposure to silica, complained of dyspnea, and had physical and $\mathrm{X}$-ray findings associated with silicosis. Pt. 4 had a long history of chronic bronchitis and physical and X-ray findings compatible with that diagnosis. Pts. 5 and 6 both had sarcoidosis, with the typical history and chest $\mathrm{X}$-ray findings associated with that disease, and fitted the syndrome of "alveolar-capillary" block. Pt. 7 although he had had a mitral commissurotomy about 6 months prior to these studies, was essentially normal as far as his pulmonary function was concerned.

\section{RESULTS}

The vital statistics and pulmonary function studies on each subject are in Table I. $\mathrm{Do}_{2}$, steady state $\mathrm{D}_{\mathrm{CO}}$, fractional $\mathrm{CO}$ uptake, $\mathrm{D}_{\mathrm{Co}}$ breath holding, and pertinent data for each subject are presented in Table II. The reader is referred to the published discussions of these methods $(1,2,5-8)$ for a detailed explanation. There are two different values for $\mathrm{D}_{\mathrm{Co}}$ steady state and fractional $\mathrm{CO}$ uptake to compare with each value of $\mathrm{Do}_{2}$, because it is possible to get the $\mathrm{CO}$ values while breathing both the air and the low $\mathrm{O}_{2}$ mixtures which are necessary for each value of
$\mathrm{Do}_{2}$. These data are also shown in Figure 3; average $\mathrm{D}_{\mathrm{co}}$ breath holding, $\mathrm{D}_{\mathrm{co}}$ steady state and fractional $\mathrm{CO}$ uptake measurements are plotted on the ordinates against the $\mathrm{Do}_{2}$ values on the common abscissa.

\section{DISCUSSION}

A. Comparisons of $D_{O_{2}}, D_{C o}$ steady state, $D_{C o}$ breath holding and fractional CO uptake

The relations between the different estimates of pulmonary diffusing capacity are best seen in Figure 3. The lowest graph is a plot of $D_{\text {co }}$ breath holding against $\mathrm{Do}_{2}$. There is a definite increase in $\mathrm{D}_{\mathrm{co}}$ breath holding as $\mathrm{Do}_{2}$ rises. The dashed lines in the lower two graphs represent the relation that would hold between $\mathrm{D}_{\mathrm{co}}$ and $\mathrm{Do}_{2}$ if the only difference between the two measurements lay in the different molecular weights and solubilities of $\mathrm{O}_{2}$ and $\mathrm{CO}$ and if the pulmonary membrane were chiefly saline (3). There are, however, many differences in the physiologic bases of $\mathrm{D}_{\mathrm{Co}}$ breath holding and $\mathrm{Do}_{2}$. For example, if the standardized time of breath holding were taken to be 20 seconds instead of $10, D_{\text {co }}$ breath holding would decrease (5), as noted earlier in this paper. In addition, recent work of Pappenheimer, Renkin, and Borrero (14) suggests that the lipid solubility of gases may be the most important fac-

TABLE II *

Simultaneous $D_{\mathrm{O}_{2}}, D_{\mathrm{Co}}$ steady state and fractional $C O$ uptake measurements, and resting $D_{C o}$ breath holding measurements on seven individuals

\begin{tabular}{|c|c|c|c|c|c|c|c|c|c|c|c|}
\hline \multirow[b]{2}{*}{ Subject } & \multicolumn{2}{|c|}{ Exercise } & \multirow[b]{2}{*}{$\begin{array}{c}\mathrm{FI}_{\mathrm{O}_{2}} \\
\%\end{array}$} & \multirow{2}{*}{$\begin{array}{c}\dot{\mathrm{V}}_{\mathrm{E}} \\
\text { Lin. }\end{array}$} & \multirow{2}{*}{$\begin{array}{l}\text { Resp. } \\
\text { rate } \\
\text { per } \\
\text { min. }\end{array}$} & \multirow{2}{*}{$\begin{array}{c}\dot{\mathrm{V}}_{\mathrm{O}_{2}} \\
\text { ml. }(S T P D) / \\
\text { min. }\end{array}$} & \multirow[b]{2}{*}{$\mathrm{R}$} & \multirow[b]{2}{*}{$\begin{array}{l}\mathrm{PaCO}_{2} \\
m m . H g\end{array}$} & \multirow[b]{2}{*}{$\begin{array}{l}\mathrm{P}^{\circ} \mathrm{AO}_{2} \\
m m . H g\end{array}$} & \multirow[b]{2}{*}{$\begin{array}{c}\mathrm{PaO}_{2} \mathrm{~F} \\
m m . \mathrm{Hg}\end{array}$} & \multirow[b]{2}{*}{$\begin{array}{l}\mathrm{P}^{\circ} \mathrm{A}_{\overline{2}}-\overline{\mathrm{Pc}_{\mathrm{O}_{2}}} \\
\mathrm{~g} \mathrm{~mm} . \mathrm{Hg}\end{array}$} \\
\hline & $\begin{array}{l}\text { Rate } \\
\text { m.p.h. }\end{array}$ & $\begin{array}{c}\text { Grade } \\
\%\end{array}$ & & & & & & & & & \\
\hline 1 & $\begin{array}{l}2.5 \\
2.5\end{array}$ & $\begin{array}{l}6 \\
6\end{array}$ & $\begin{array}{l}20.93 \\
12.72\end{array}$ & $\begin{array}{l}32.9 \\
34.6\end{array}$ & $\begin{array}{l}44 \\
46\end{array}$ & $\begin{array}{l}1,469 \\
1,096\end{array}$ & $\begin{array}{l}0.81 \\
0.80\end{array}$ & $\begin{array}{l}38 \\
35\end{array}$ & $\begin{array}{r}102 \\
47\end{array}$ & $\begin{array}{l}92 \\
38\end{array}$ & $\begin{array}{l}17 \\
17\end{array}$ \\
\hline 2 & $\begin{array}{l}0 \\
0\end{array}$ & $\begin{array}{l}0 \\
0\end{array}$ & $\begin{array}{l}20.93 \\
13.97\end{array}$ & $\begin{array}{r}10.2 \\
9.8\end{array}$ & $\begin{array}{l}19 \\
16\end{array}$ & $\begin{array}{l}337 \\
282\end{array}$ & $\begin{array}{l}0.74 \\
0.90\end{array}$ & $\begin{array}{l}45 \\
43\end{array}$ & $\begin{array}{l}94 \\
51\end{array}$ & $\begin{array}{l}78 \\
44\end{array}$ & $\begin{array}{l}13 \\
13\end{array}$ \\
\hline 3 & $\begin{array}{l}1.3 \\
1.3\end{array}$ & $\begin{array}{l}6 \\
6\end{array}$ & $\begin{array}{l}20.93 \\
12.72\end{array}$ & $\begin{array}{l}34.5 \\
48.6\end{array}$ & $\begin{array}{l}26 \\
35\end{array}$ & $\begin{array}{l}1,342 \\
1,405\end{array}$ & $\begin{array}{l}0.89 \\
0.95\end{array}$ & $\begin{array}{l}39 \\
34\end{array}$ & $\begin{array}{r}104 \\
54\end{array}$ & $\begin{array}{l}92 \\
37\end{array}$ & $\begin{array}{l}25 \\
25\end{array}$ \\
\hline 4 & $\begin{array}{l}1.3 \\
1.3\end{array}$ & $\begin{array}{l}6 \\
6\end{array}$ & $\begin{array}{l}20.93 \\
13.97\end{array}$ & $\begin{array}{l}30.0 \\
25.6\end{array}$ & $\begin{array}{l}34 \\
30\end{array}$ & $\begin{array}{l}956 \\
619\end{array}$ & $\begin{array}{l}0.80 \\
0.91\end{array}$ & $\begin{array}{l}46 \\
36\end{array}$ & $\begin{array}{l}93 \\
59\end{array}$ & $\begin{array}{l}75 \\
42\end{array}$ & $\begin{array}{l}26 \\
26\end{array}$ \\
\hline 5 & $\begin{array}{l}1 \\
1\end{array}$ & $\begin{array}{l}0 \\
0\end{array}$ & $\begin{array}{l}20.93 \\
13.97\end{array}$ & $\begin{array}{l}24.2 \\
35.8\end{array}$ & $\begin{array}{l}32 \\
50\end{array}$ & $\begin{array}{l}604 \\
510\end{array}$ & $\begin{array}{l}0.80 \\
1.02\end{array}$ & $\begin{array}{l}35 \\
28\end{array}$ & $\begin{array}{r}105 \\
70\end{array}$ & $\begin{array}{l}60 \\
31\end{array}$ & $\begin{array}{l}43 \\
43\end{array}$ \\
\hline 6 & $\begin{array}{l}0 \\
0\end{array}$ & $\begin{array}{l}0 \\
0\end{array}$ & $\begin{array}{l}20.93 \\
13.97\end{array}$ & $\begin{array}{l}13.2 \\
13.3\end{array}$ & $\begin{array}{l}40 \\
46\end{array}$ & $\begin{array}{l}301 \\
230\end{array}$ & $\begin{array}{l}0.88 \\
0.89\end{array}$ & $\begin{array}{l}41 \\
36\end{array}$ & $\begin{array}{r}102 \\
59\end{array}$ & $\begin{array}{l}86 \\
46\end{array}$ & $\begin{array}{l}21 \\
21\end{array}$ \\
\hline 7 & $\begin{array}{l}1.5 \\
1.5\end{array}$ & $\begin{array}{l}0 \\
0\end{array}$ & $\begin{array}{l}20.93 \\
12.72\end{array}$ & $\begin{array}{l}21.0 \\
22.3\end{array}$ & $\begin{array}{l}13 \\
12\end{array}$ & $\begin{array}{l}961 \\
952\end{array}$ & $\begin{array}{l}0.85 \\
0.78\end{array}$ & $\begin{array}{l}37 \\
30\end{array}$ & $\begin{array}{r}108 \\
54\end{array}$ & $\begin{array}{l}95 \\
49\end{array}$ & $\begin{array}{l}15 \\
15\end{array}$ \\
\hline
\end{tabular}




\begin{tabular}{|c|c|c|c|c|c|c|c|c|c|}
\hline Subject & $\underset{\%}{\mathrm{~V}_{\mathrm{D}} / \mathrm{V}_{\mathrm{T}}}$ & $\dot{\mathrm{Q}}_{\mathrm{v}_{\%}} / \dot{\mathrm{Q}}_{\mathrm{T}}$ & $\frac{\begin{array}{c}\mathrm{D}_{\mathrm{O}_{2}} \\
m \mathrm{~m} .\end{array}}{\min . \times m m \cdot H g}$ & $\begin{array}{c}\text { FIco } \\
\%\end{array}$ & $\begin{array}{c}\text { CO } \\
\text { uptake } \\
\text { ml./min. }\end{array}$ & $\begin{array}{l}\text { PoAco } \\
m m . H g\end{array}$ & $\begin{array}{c}\text { Frac- } \\
\text { tional } \\
\text { CO } \\
\text { uptake } \\
\% \\
\end{array}$ & $\begin{array}{c}\begin{array}{c}\text { Dco steady } \\
\text { state } \\
\text { ml. }\end{array} \\
\text { min. Xmm. Hg }\end{array}$ & 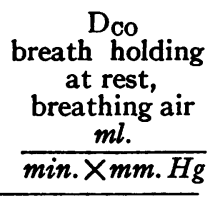 \\
\hline 1 & $\begin{array}{l}24 \\
43\end{array}$ & 3 & 65 & $\begin{array}{l}0.092 \\
0.089\end{array}$ & $\begin{array}{l}12.6 \\
11.2\end{array}$ & $\begin{array}{l}0.24 \\
0.17\end{array}$ & $\begin{array}{l}46 \\
40\end{array}$ & $\begin{array}{l}52 \\
66\end{array}$ & 37,41 \\
\hline 2 & $\begin{array}{l}54 \\
50\end{array}$ & 8.5 & 22 & $\begin{array}{l}0.094 \\
0.107\end{array}$ & $\begin{array}{l}3.4 \\
3.2\end{array}$ & $\begin{array}{l}0.05 \\
0.20\end{array}$ & $\begin{array}{l}43 \\
36\end{array}$ & $\begin{array}{l}71 \\
16\end{array}$ & $13,13,18$ \\
\hline 3 & $\begin{array}{l}32 \\
38\end{array}$ & 4 & 56 & $\begin{array}{l}0.098 \\
0.088\end{array}$ & $\begin{array}{l}10.7 \\
12.2\end{array}$ & $\begin{array}{l}0.34 \\
0.30\end{array}$ & $\begin{array}{l}34 \\
30\end{array}$ & $\begin{array}{l}32 \\
41\end{array}$ & 20,31 \\
\hline 4 & $\begin{array}{l}50 \\
47\end{array}$ & 8 & 24 & $\begin{array}{l}0.148 \\
0.098\end{array}$ & $\begin{array}{r}10.0 \\
6.7\end{array}$ & $\begin{array}{l}0.46 \\
0.26\end{array}$ & $\begin{array}{l}25 \\
29\end{array}$ & $\begin{array}{l}22 \\
26\end{array}$ & 12 \\
\hline 5 & $\begin{array}{l}53 \\
60\end{array}$ & 20 & 12 & $\begin{array}{l}0.095 \\
0.088\end{array}$ & $\begin{array}{l}2.7 \\
2.0\end{array}$ & $\begin{array}{l}0.47 \\
0.50\end{array}$ & $\begin{array}{r}13 \\
7\end{array}$ & $\begin{array}{l}6 \\
4\end{array}$ & $7,7,8,9$ \\
\hline 6 & $\begin{array}{l}54 \\
53\end{array}$ & 6.5 & 11 & $\begin{array}{l}0.138 \\
0.083\end{array}$ & $\begin{array}{l}4.1 \\
2.9\end{array}$ & $\begin{array}{l}0.34 \\
0.13\end{array}$ & $\begin{array}{l}28 \\
36\end{array}$ & $\begin{array}{l}12 \\
22\end{array}$ & 14 \\
\hline 7 & $\begin{array}{l}21 \\
17\end{array}$ & 3.5 & 63 & $\begin{array}{l}0.154 \\
0.067\end{array}$ & $\begin{array}{r}16.7 \\
7.3\end{array}$ & $\begin{array}{l}0.35 \\
0.17\end{array}$ & $\begin{array}{l}54 \\
50\end{array}$ & $\begin{array}{l}48 \\
42\end{array}$ & 22 \\
\hline
\end{tabular}

${ }^{*} \mathrm{~F}_{\mathrm{I}_{2}}$ is dry inspired $\mathrm{O}_{2}$ concentration in $\%$.

$\dot{\mathrm{V}}_{\mathrm{E}}$ is expired minute ventilation in liters $\mathrm{STPD} / \mathrm{min}$.

$\mathrm{V}_{2}$ is the $\mathrm{O}_{2}$ consumption in $\mathrm{ml}$. STPD/min.

$R$ is the respiratory exchange ratio.

$\mathrm{PaCO}_{2}$ is the arterial $\mathrm{CO}_{2}$ tension in $\mathrm{mm} . \mathrm{Hg}$ measured directly.

$\mathrm{P}^{\mathrm{P}_{\mathrm{O}}} \mathrm{O}_{2}$ is the calculated effective alveolar $\mathrm{O}_{2}$ tension in $\mathrm{mm}$. $\mathrm{Hg}$.

$\mathrm{PaO}_{2}$ is the arterial $\mathrm{O}_{2}$ tension in $\mathrm{mm}$. $\mathrm{Hg}$ measured directly.

$\mathrm{PcO}_{2}$ is mean capillary $\mathrm{O}_{2}$ tension in $\mathrm{mm}$. $\mathrm{Hg}$.

$\mathrm{V}_{\mathrm{D}} / \mathrm{V}_{\mathrm{T}}$ is dead space volume/tidal volume in \%: normally less than $25 \%$.

$\dot{Q}_{\mathrm{va}} / \dot{Q}_{\mathrm{T}}$ is the "physiological" shunt of mixed venous blood across the lung over the total capillary blood flow in \%. Called "percentage venous admixture." Normally less than $6 \%$.

$\mathrm{D}_{\mathrm{O}_{2}}$ is pulmonary diffusing capacity for $\mathrm{O}_{2}$ in $\mathrm{ml}$. STPD $/ \mathrm{min} . / \mathrm{mm}$. $\mathrm{Hg}$.

F Ico is dry inspired CO concentration in $\%$.

$\mathrm{Pe}_{\mathrm{Aco}}$ is the calculated effective alveolar $\mathrm{CO}$ tension in $\mathrm{mm}$. $\mathrm{Hg}$ corrected for the increase in $\mathrm{COHb}$ during the experiment.

$\mathrm{D}_{\mathrm{CO}}$ is pulmonary diffusing capacity for CO, either steady state or breath holding, in $\mathrm{ml}$. STPD $/ \mathrm{min} . / \mathrm{mm}$. $\mathrm{Hg}$.

tor in their diffusion through the pulmonary membrane, which would change the theoretical relation between $\mathrm{D}_{\mathrm{Co}}$ and $\mathrm{Do}_{2}$. Patients 2 and 6 were studied at rest both for $D_{\text {co }}$ breath holding and $\mathrm{Do}_{2}$. Patients 4 and 5 , whose $\mathrm{D}_{\mathrm{co}}$ breath holding was measured at rest and whose $\mathrm{Do}_{2}$ during exercise, had diagnoses of long standing chronic bronchitis and sarcoidosis, respectively. It is apparent that these patients were not able to increase their pulmonary diffusing capacity on exercise (7) to the same extent as normal subjects, and for this reason there is less difference between the breath holding values determined at rest and the $\mathrm{DO}_{2}$ values obtained during exercise. Patients 1,3 , and 7 on the other hand, who were con- sidered to be in better physical condition than the others, did presumably increase their $\mathrm{Do}_{2}$ on exercise which displaced their points to the right. It should be noted that the $\mathrm{DO}_{2}$ measurements on relatively healthy individuals, are more successful technically when done during exercise. At the time this study was done, we were not able to make $\mathrm{D}_{\mathrm{CO}}$ breath holding measurements during exercise. Presumably, $\mathrm{D}_{\mathrm{co}}$ breath holding would have increased with exercise, displacing the values for patients 1,3 , and 7 upwards, as more recent studies have shown (15). All in all the findings are not unreasonable in view of the circumstances under which they were obtained.

The middle graph in Figure 3 is a plot of simul- 

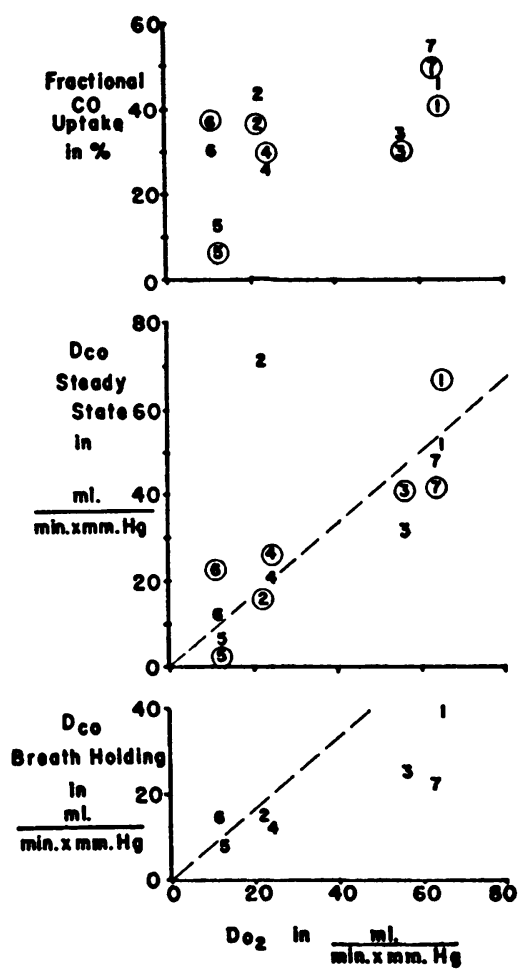

Fig. 3. Fractional CO Uptake, Dco Steady State and Dco Breath Holding Plotted against $\mathrm{DO}_{2}$

The numbers refer to the particular subject; a circle about a number indicates that value was obtained breathing an $\mathrm{O}_{2}$ concentration less than 20.93 per cent. The dashed lines are the theoretical relationships between the pulmonary diffusing capacity for $\mathrm{O}_{2}$ and that for $\mathrm{CO}$; $\mathrm{DO}_{2}=1.23$ Dco. Individuals $1,3,4,5$, and 7 were studied during exercise, except for the $D_{c o}$ breath holding which was measured at rest in all subjects. Individuals 2 and 6 were studied in rest in all tests.

taneous measurements of $\mathrm{D}_{\mathrm{co}}$ steady state against $\mathrm{Do}_{2}$. In this comparison, the level of exercise was obviously the same during both tests. These two methods are analogous in that both are performed during a steady state and, in both, alveolar tensions $\left(\mathrm{Po}_{2}\right.$ or $\left.\mathrm{P}_{\mathrm{Co}}\right)$ are calculated from the Bohr equation, assuming that arterial $\mathrm{PCO}_{2}$ is a good estimate of mean alveolar $\mathrm{PCO}_{2}$. The value of $\mathrm{D}_{\mathrm{Co}}$ steady state is sensitive to errors in arterial $\mathrm{PCO}_{2}$ particularly when the fractional uptake of $\mathrm{CO}$ is high, and to errors in inspired and expired $\mathrm{CO}$ analysis, particularly when the ratio of dead space to tidal volume is high. A summation of such errors presumably accounts for the very high value recorded for $D_{c o}$ in Patient 2 when breathing $\mathrm{CO}$ in room air. In all other instances the correspondence between the two methods is as good as could be expected in view of known limits of analytical accuracy.

The topmost graph in Figure 3 is a plot of fractional $\mathrm{CO}$ uptake against $\mathrm{Do}_{2}$. Although there is a general tendency for fractional uptake to rise with increasing values of $\mathrm{Do}_{2}$, there is a considerable amount of scatter. This is probably due to the fact that fractional $\mathrm{CO}$ uptake decreases with increasing alveolar ventilation as well as decreasing with a lowered pulmonary diffusing capacity (5) ; in these studies the alveolar minute ventilation varied significantly. It is possible to calculate a value of $D_{c o}$ from the fractional $C O$ uptake if alveolar ventilation is known (16). This in effect corrects fractional $\mathrm{CO}$ uptake for variations in alveolar ventilation.

\section{B. Critique of the measurement of $D_{O_{2}}$}

The accuracy of $\mathrm{Do}_{2}$ estimation by the Lilienthal-Riley technique has been discussed before (7). The method is inaccurate unless the end gradient, or mean alveolar to end capillary blood $\mathrm{Po}_{2}$ difference is $6 \mathrm{~mm}$. $\mathrm{Hg}$ or more. Since both exercise and 'alveolar-capillary block' cause this gradient to rise, the circumstances of the present studies were to the advantage of the method. If the gradients are sufficiently large, the estimate of $\mathrm{DO}_{2}$ by this method appears to be good in health or in disease. The rate of combination of $\mathrm{O}_{2}$ with intracorpuscular $\mathrm{Hb}$, although faster than that for $\mathrm{CO}$, interferes with the uptake of $\mathrm{O}_{2}$ by the blood in the lungs in an analogous manner (17). The degree of underestimation of $\mathrm{Do}_{2}$ because of this theoretical error is not at present known.

\section{Critique of the measurement of $D_{c o}$ steady state and breath holding}

The presence of a $\mathrm{CO}$ tension in the capillary blood will interfere with the diffusion of $\mathrm{CO}$ into blood and if it is not allowed for, will produce an apparent underestimate of the true pulmonary diffusing capacity (17). There are two reasons for the existence of a significant capillary blood $\mathrm{P}_{\mathbf{c o}}$, the first of which is the presence in the blood of $\mathrm{COHb}$ in a large enough concentration to have a significant $\mathrm{P}_{\mathrm{CO}}$ in equilibrium with it. Although the blood $\mathrm{COHb}$ was not analyzed in these studies, the patients were all non-smokers, so their ini- 
tial mixed venous $\mathrm{COHb}$ would have been expected to lie between 0 and 5 per cent saturation (18). The effect of this $\mathrm{COHb}$ was ignored in both steady state and breath holding $\mathrm{D}_{\mathrm{co}}$ measurements. During the steady state procedure there was, in addition, a significant increase in mixed venous $\mathrm{COHb}$, which can be calculated from the total $\mathrm{CO}$ uptake and an assumed blood volume. The values of alveolar $\mathrm{P}_{\mathrm{Co}}$ used to calculate $\mathrm{D}_{\text {co }}$ steady state in Table II have been corrected by subtracting from the actual alveolar $P_{c o}$ the tension of $\mathrm{CO}$ in equilibrium with the average mixed venous $\mathrm{COHb}$ during the test at the mean capillary $\mathrm{Po}_{2}$. The calculation of $\mathrm{D}_{\mathrm{co}}$ breath holding needs no correction for blood $\mathrm{COHb}$ except in exceptional circumstances because : (a) the total amount of $\mathrm{CO}$ absorbed in the procedure is about a quarter of that taken up in the steady state $\mathrm{D}_{\text {co }}$ measurement; (b) in addition, the alveolar $\mathrm{P}_{\mathrm{co}}$ is much higher; in the example of the calculation of breath holding $\mathrm{D}_{\mathrm{CO}}$ of Patient 2 cited above, compare the alveolar $\mathrm{CO}$ concentration of 0.106 per cent initially, falling to 0.069 per cent at the end of 10 seconds, with the steady state alveolar $\mathrm{CO}$ concentration in Table II of 0.2 $\mathrm{mm} . \mathrm{Hg} / 713$ or 0.028 per cent $\mathrm{CO}$.

The second cause of a $\mathrm{CO}$ tension in the capillary blood during its passage through the alveolus is the slowness of the reaction of $\mathrm{CO}$ with intracellular $\mathrm{Hb}$ which prevents its being bound in the blood and allows it to pile up in solution in the plasma. This problem does in fact exist (17), but will result in an underestimate of $D_{c o}$ by the same proportion in either the breath holding or steady state methods of estimating $\mathrm{D}_{\mathrm{CO}}$. The rate of combination of $\mathrm{CO}$ and $\mathrm{Hb}$ decreases as the blood $\mathrm{O}_{2}$ tension rises. Therefore, measurements of $D_{c o}$ by either breath holding or steady state methods must be done at a relatively constant alveolar $\mathrm{Po}_{2}$ (actually constant capillary blood $\mathrm{Po}_{2}$ ) if the test is to be standardized. In the present studies all the breath holding tests were done under conditions which could reasonably be expected to produce an alveolar $\mathrm{Po}_{2}$ of about $100 \mathrm{~mm}$. $\mathrm{Hg}$. On the other hand, the steady state $D_{c o}$ measurements on each subject were made with two different alveolar $\mathrm{Po}_{2}$ levels : $100 \mathrm{~mm}$. $\mathrm{Hg}$ and $55 \mathrm{~mm}$. $\mathrm{Hg}$. At the lower $\mathrm{O}_{2}$ tension, the rate of combination of $\mathrm{CO}$ and $\mathrm{Hb}$ should have been greater; as a result the capillary $P_{0 o}$ should have been less and the calculated steady state $D_{\text {co }}$ should have been greater. However, the calculated value of steady state $\mathrm{D}_{\mathrm{co}}$, while breathing a low $\mathrm{O}_{2}$ mixture, was greater than that when breathing air in only 4 out of 7 instances (Figure 3 and Table II). Since other data definitely show an increase in calculated $D_{\mathrm{Co}}$ by either steady state or breath holding techniques when the alveolar $\mathrm{PO}_{2}$ is decreased (5, 9 ), the failure of the present measurements to show a similar change must probably be accounted for by the presence of analytical inaccuracies which conceal this effect. It must be recognized that the determinations of diffusing capacity reported in this paper put considerable strain on the analytical techniques which were available.

In the breath holding technique the calculation of the initial $\mathrm{CO}$ concentration in the expired alveolar gas depends upon the assumption that the inspired $\mathrm{CO}-\mathrm{He}$ mixture is completely mixed with alveolar gas before significant absorption of $\mathrm{CO}$ into the blood takes place. The validity of this assumption is in turn based on (a) calculations of the rapidity with which diffusion mixes gases in the finer divisions of the respiratory tree (10), and (b) the fact that the expired alveolar $\mathrm{CO}$ concentration, when measured after various intervals of breath holding in normal subjects and plotted against time, back-extrapolates to the initial CO concentration as calculated on the basis of this assumption. Expired alveolar gas samples were obtained at various durations of breath holding in the present subjects (these data are not all included) and observation (b) is also true for them. Therefore, it appears valid to calculate the initial $\mathrm{CO}$ concentration in the collected expired alveolar sample from the dilution of the inspired $\mathrm{He}$ concentration, but the question may arise as to whether the sample derives from alveoli which have local diffusing capacities which are representative of the pulmonary diffusing capacity of the lung as a whole. $\mathrm{D}_{\mathrm{co}}$ breath holding (measured over a 10-second period) in normal subjects and in a limited number of patients with sarcoidosis and emphysema, varies less than 10 per cent when the expired alveolar sample analyzed is from the early or late parts of the expiration (15). Since the early parts of the expired alveolar gas come from different alveoli than the later parts (19), this suggests that the different parts of the expired 
alveolar gas are reasonably representative in respect to the total pulmonary diffusing capacity.

The steady state $\mathrm{D}_{\mathrm{co}}$ method and $\mathrm{Do}_{2}$ method for measuring pulmonary diffusing capacity are both subject to theoretical errors if pulmonary diffusing capacity is not distributed evenly throughout the lung in relation to alveolar ventilation (16), just as the breath holding $D_{\text {co }}$ estimate is subject to error if pulmonary diffusing capacity is not distributed throughout the lung evenly with respect to alveolar volume. In comparing $\mathrm{D}_{\mathrm{Co}}$ breath holding with either $\mathrm{Do}_{2}$ or $\mathrm{D}_{\mathrm{Co}}$ steady state it must be borne in mind that conditions are not strictly comparable during the tests. The breathing maneuvers performed in the breath holding test may alter the state and number of the perfused capillaries and may do so to a different degree in the different subjects. Although the $\mathrm{D}_{\mathrm{Co}}$ breath holding could not have been expected to be exactly equal to $\mathrm{D}_{\mathrm{Co}}$ steady state or to $\mathrm{Do}_{2}$, particularly when the latter were measured during exercise, one of the purposes of this investigation was to determine whether it provides a convenient and reliable means of evaluating the state of the diffusing surface in patients. The results are sufficiently encouraging to warrant a more extensive investigation of the method.

\section{SUMMARY AND CONCLUSIONS}

Measurements of $D_{\text {Co }}$ were made at rest on seven subjects by a modification of Krogh's breath holding technique. These findings were compared to simultaneous steady state measurements of $\mathrm{DO}_{2}$ by the Lilienthal-Riley technique, of $\mathrm{D}_{\mathrm{Co}}$ by the Filley technique and of fractional $\mathrm{CO}$ uptake as described by Bates. The latter methods were applied during exercise in five of the seven subjects. All but one of the subjects were hospital patients and together they provided a wide range of values for pulmonary diffusing capacity.

It is concluded for the present that the methods for the estimation of steady state $\mathrm{Do}_{2}$ and $\mathrm{D}_{\mathrm{CO}}$ provide similar values when allowance is made for the differences in physical characteristics between the two gases. Estimates obtained by the $\mathrm{CO}$ breath holding technique at rest show directional changes which are comparable to those obtained by the other methods during exercise, although the absolute values are lower. The frac- tional $\mathrm{CO}$ uptake, when uncorrected for changes in ventilation rate, is less reliable.

The optimum conditions for each method vary, and further studies of the advantages and limitations of each are required.

\section{ACKNOWLEDGMENT}

The authors wish to acknowledge the stimulation and help of Dr. J. H. Comroe, Jr., and of the entire staff of the Pulmonary Function Laboratory of the Hospital of the University of Pennsylvania.

\section{REFERENCES}

1. Lilienthal, J. L., Jr., Riley, R. L., Proemmel, D. D., and Franke, R. E., An experimental analysis in man of the oxygen pressure gradient from alveolar air to arterial blood during rest and exercise at sea level and at altitude. Am. J. Physiol., 1946, 147, 199.

2. Filley, G. F., MacIntosh, D. J., and Wright, G. W., Carbon monoxide uptake and pulmonary diffusing capacity in normal subjects at rest and during exercise. J. Clin. Invest., 1954, 33, 530.

3. Krogh, A., and Krogh, M., On the rate of diffusion of carbonic oxide into the lungs of man. Skandinav. Arch. f. Physiol., 1909, 23, 236.

4. Krogh, M., Diffusion of gases through the lungs of man. J. Physiol., 1915, 49, 271.

5. Forster, R. E., Fowler, W. S., Bates, D. V., and Van Lingen, B., The absorption of carbon monoxide by the lungs during breath holding. J. Clin. Invest., 1954, 33, 1135.

6. Bates, D. V., The uptake of carbon monoxide in health and in emphysema. Clin. Sc., 1952, 11, 21.

7. Riley, R. L., Shepard, R. H., Cohn, J. E., Carroll, D. G., and Armstrong, B. W., Maximal diffusing capacity of the lungs. J. Applied Physiol., 1954, 6, 573.

8. Riley, R. L., Riley, M. C., and Hill, N. McD., Diffuse pulmonary sarcoidosis: Diffusing capacity during exercise and other lung function studies in relation to ACTH therapy. Bull. Johns Hopkins Hosp., 1952, 91, 345.

9. Forster, R. E., Unpublished observations.

10. Rauwerda, P. E., Unequal ventilation of different parts of the lung. Thesis, Gröningen Univ., 1946.

11. Darling, R. C., Cournand, A., and Richards, D. W., Jr., Studies on intrapulmonary mixture of gases. III. An open circuit method for measuring residual air. J. Clin. Invest., 1940, 19, 609.

12. Cournand, A., Baldwin, E. deF., Darling, R. C., and Richards, D. W., Jr., Studies on intrapulmonary mixture of gases. IV. The significance of the pulmonary emptying rate and a simplified open circuit measurement of residual air. J. Clin. Invest., 1941, 20, 681. 
13. Comroe, J. H., Jr., and Fowler, W. S., Lung function studies. VI. Detection of uneven alveolar ventilation during a single breath of oxygen. Am. J. Med., 1951, 10, 408.

14. Pappenheimer, J. R., Renkin, E. M., and Borrero, L. M., Filtration, diffusion and molecular sieving through peripheral capillary membranes. A contribution to the pore theory of capillary permeability. Am. J. Physiol., 1951, 167, 13.

15. Ogilvie, C., Forster, R. E., and Morton, J. W., To be published.

16. Forster, R. E., Fowler, W. S., and Bates, D. V.,
Considerations on the uptake of carbon monoxide by the lungs. J. Clin. Invest., 1954, 33, 1128.

17. Roughton, F. J. W., The average time spent by the blood in the human lung capillary and its relation to the rates of $\mathrm{CO}$ uptake and elimination in man. Am. J. Physiol., 1945, 143, 621.

18. Forbes, W. H., Sargent, F., and Roughton, F. J. W., The rate of carbon monoxide uptake by normal men. Am. J. Physiol., 1945, 143, 594.

19. Fowler, W. S., Lung function studies. III. Uneven pulmonary ventilation in normal subjects and in patients with pulmonary disease. J. Applied Physiol., 1949, 2, 283. 